Helsemyndighetene har etter vårt syn fulgt en god og faglig trygg vei de siste ti årene, en vei som også er i tråd med dagens politiske føringer. Innføring av PET-skanning som undersøkelsesmetode bør skje styrt og planlagt, fordi unødig bruk av metoden kan gå på bekostning av billigere og like gode metoder som er tilgjengelige i sykehusene.

Vi vil fremheve tre nøkkelfaktorer som kjennetegner disse prosessene: krav til dokumentasjon av klinisk nytte og positiv kostnad-nytte-effekt, involvering av fagmiljøene i prosessene og et nasjonalt organ som kan gi beslutningstakere råd om innføring av kostbart og avansert utstyr.

\section{Inger Natvig Norderhaug}

inger.norderhaug@kunnskapssenteret.no Nasjonalt kunnskapssenter for helsetjenesten og

Institutt for samfunnsmedisin

Universitetet i Tromsø

\section{Ånen Ringard}

Sekretariatet for Nasjonalt råd for kvalitet og prioritering i helsetjenesten

\section{Berit Mørland}

Nasjonalt kunnskapssenter for helsetjenesten

Sekretariatet for Nasjonalt råd for kvalitet og prioritering i helsetjenesten

\section{Litteratur}

1. Brøyn MB, Fuglehaug W. PET-skanning: fremtidens diagnostikk. Aftenposten 30.8.2010.

2. Smiseth OA, Myhre ES, Aas M et al. Positron emisjonstomografi (PET) - diagnostisk og klinisk nytteverdi. Rapport nr. 8/2000. Oslo: Senter for medisinsk metodevurdering, 2000.

3. Mørland B. Positronemisjonstomografi (PET) diagnostisk og klinisk nytteverdi. Rapport nr. 6/2003. Oslo: Senter for medisinsk metodevurdering, 2003.

4. Graff BA. PET - diagnostisk og klinisk nytteverdi. Oslo: Nasjonalt kunnskapssenter for helsetjenesten, 2006.

5. Johansen K, Mørland B. Prosjektrapport. Bruk av og fremtidig behov for PET i Norge. Oslo: Nasjonalt råd for kvalitet og prioritering, 2008.

6. Graff BA, Jeppesen E, Movik E et al. Estimering av behovet for PET/CT i 2020. Oslo: Nasjonalt kunnskapssenter for helsetjenesten, 2009.

7. Jeppesen E, Juvet L. Klinisk nytte av PET integrert med CT for ikke-småcellet lungekreft. Metodevarsel nr. 3/2010. Oslo: Nasjonalt kunnskapssenter for helsetjenesten, 2010.

8. Nasjonalt råd for kvalitet og prioritering i helsetjenesten. Positronemisjonstomografi. www.kvalitetogprioritering.no/Saker/12488.cms (13.12.2010).

\title{
Epikriser gir læring
}

\author{
Epikrisen er et viktig virkemiddel i kommunikasjonen mellom \\ sykehusene og fastlegene og bidrar til kontinuitet i behandlingen. \\ Men hvem skal og hvem kan epikrisen sendes til?
}

Helse- og omsorgsdepartementet kom 29.6. 2010 med presiseringer i journalforskriften $(1,2)$. Som hovedregel skal det nå sendes epikrise til henvisende helsepersonell i tillegg til pasientens fastlege.

\section{Krav om oppfølgingsansvar?}

I pasientjournalforskriftens $\S 9$ står det at epikrise skal «sendes det helsepersonell som trenger opplysningene for å kunne gi pasienten forsvarlig oppfølgning» (1). Tredje ledd i samme paragraf åpner for at epikrisen også kan sendes til innleggende/ henvisende helsepersonell. Denne bestemmelsen er inntil nå blitt tolket svært restriktivt, slik at man for å kunne sikkerhet for pasientene. Sentralstyret i Legeforeningen vedtok 28.4. 2008, etter forslag fra utvalget, en handlingsplan for pasientsikkerhet (4). Utvalget arbeider kontinuerlig med å foreslå tiltak som skal oppfylle handlingsplanen. Ett av disse har vært å stimulere helseforetak til å sende epikriser til legevaktleger og andre innleggende leger, slik at henvisende lege i læringsøyemed kan få kjennskap til endelig diagnose og behandling.

Departementets presiseringer om utsendelse av epikrise er en kjærkommen tolking av regelverket og understøtter utvalgets syn. Det som gjenstår, er at de regionale helseforetakene, som er adressater

\section{«Som hovedregel skal det nå sendes epikrise til henvisende helsepersonell i tillegg til pasientens fastlege»}

motta epikrise må ha et oppfølgingsansvar for pasienten, med mindre vedkommende aktivt gir sitt samtykke. De fleste legevaktleger har ikke noe slikt oppfølgingsansvar og har derfor heller ikke hatt muligheten til å lære gjennom å få tilbakemelding på diagnostisering og eventuell påbegynt behandling.

Problemstillingen ble reist gjennom en henvendelse fra Helse Sør-Øst til Helseog omsorgsdepartementet 15.10. 2009 (3), etter at helsetilsynet i Telemark for noen år tilbake tok et initiativ for at legevaktlegene skulle kunne dra nytte av epikrisen til å lære av og eventuelt korrigere sin atferd. Helse- og omsorgsdepartementet har i brev av 29.6. 2010 (2) til Helse Sør-Øst, med gjenpart til øvrige regionale helseforetak, kommet med presiseringer om at epikrisen som hovedregel skal sendes til henvisende helsepersonell i tillegg til pasientens fastlege. Dette vil måtte føre til endret praksis for de fleste helseforetak.

\section{Læring}

Legeforeningens utvalg for kvalitet og pasientsikkerhet er opptatt av hvordan epikrisen kan bidra til læring og endring av klinisk praksis og dermed til bedre for presiseringen, tar de nødvendige initiativer for å endre praksis i den kliniske hverdag.

\section{Gunnar Andersen \\ gunnara@online.no \\ Porsgrunn legesenter \\ Augestadveien 7 \\ 3915 Porsgrunn}

Oppgitte interessekonflikter: Forfatteren er medlem av Legeforeningens utvalg for kvalitet og pasientsikkerhet.

\section{Litteratur}

1 FOR 2000-12-21 nr 1385: Forskrift om pasientjournal. www.lovdata.no/cgi-wift/ldles?doc=/sf/ sf/sf-20001221-1385.html (15.10.2010).

2. Brev av 29.6. 2010 til Helse Sør-Øst RHF. Vedrørende regelverket om utsending av epikriser. Oslo: Helse- og omsorgsdepartementet, 2010.

3. Brev av 15.10. 2009 til Helse- og omsorgsdepartementet. Anmodning om vurdering av regelverket om utsending av epikrise. Hamar: Helse SørØst RHF, 2009.

4. Legeforeningens handlingsplan for pasientsikkerhet. www.legeforeningen.no/id/146188.0 (18.12.2010).

Mottatt 1.10. 2010, første revisjon innsendt 14.11. 2010, godkjent 23.12. 2010. Medisinsk redaktør Mette Sagsveen. 